\title{
Reaping the Royal Rewards of Risk-Taking
}

\author{
Fengjuan $\mathrm{Wu}$ \\ School of foreign languages \\ Wuhan Textile University \\ Wuhan, P.R.China, 430073 \\ E-mail:birderry@sina.com
}

\author{
Zhengshun Han \\ School of foreign languages \\ Wuhan Textile University \\ Wuhan, P.R.China 430073 \\ E-mail: hanzhengshun@126.com
}

\begin{abstract}
Watching English movies remains the most popular way to learn English, to understand western history, culture, scenes, sight and sounds social customs and state, plus philosophic thinking for classic movies, more often than not, are rich and vivid in content, more visual in terms of scenes; terse in dialogue; pregnant with meaning; unique in acting. They, in a way, showcase the evolution and experience of western civilization realistically and artistically. Thus greatly enhancing our full awareness of it. This movie of "Far and Away", shot by American Universal Company in1992, starring Joseph (Tom Cruise) and Shannon (Nicole Kideman) is an Irish version of American Dream: America is an attractive land of flowing milk and honey, a field of opportunities and challenges. It relates the incredible love story between Joseph, son of an unfortunate tenant, and Shannon, daughter of a rich landlord. These two hearts were both pursuing for freedom and independence. One is haunted by his father's last words: "A man is worthless and soulless until he has had his own land". The other was well-educated in manners, open-minded and eager to seek a new life in the New World, but unready to face obstacles and setbacks. These two dream-catchers united accidentally, set for America, after some setbacks, head just in time for the rush for Land Run, which beckoned them to the west, in Texas in 1893 upon which their fate lies. This movie is based on the real story of the director's great grand-father Ralph Tomlin who won in the Cherokee Strip Land Race, whose story was often talked about till now. This movie is indeed wide in perspective, with vast oceans, savage lands, picturesque views and magnificent scenes with indelible impression.This paper intends to delineate this movie from three respects: (1)Joseph: a humble but young big-dreamer, who stumbles and falls and rises again to accomplish his land dream steadfastly and resolutely. (2)Shannon: an obstinate, headstrong but modern lady who downgrades herself to make her dream come true by hook or by crook.(3)Their landclaiming dream links their fate together, and through thick and thin, they witness its coming into being.
\end{abstract}

Keywords-American dream; Swan flesh; delicate and delicious

\section{INTRODUCTION}

Literature review of this movie reveals that in this country there are three commentaries: that is,(1).Yang Miao."The Similarities and Contrasts Concerning Sino-US Western Development Strategy From the Perspective of Far and Away".(Social Science.p550.).This paper compares and contrasts the Sino-US Western Development
Strategies.(2).Wei Wei."A Glimpse of American History and Culture From Far and Away".(Movie Literature.2012.No.19. pp99-100,).This paper delineates three significant cultural events in America: westward movement; racial genocide of the natives and the birth of American dream.(3). Weifeng Geng's." Joseph's Aspiring for Dreams in Far and Away.(Movie Literature.2014.No.20.pp74-75.).This paper holds that Joseph, the protagonist, harbors the dream of liberty, equality and land, he struggles for it determinedly until it came true at last. Abroad, this movie received mixed reviews.(1)Roger Ebert highly praised this movie's cinematography but strongly criticized its script: Far and Away is a movie that integrates astonishing visual splendor into a story so simple-minded that it intends for adolescent. It's so depressing that such a lavish and expensive production, starring such an important actor as Tom Cruise, could be dedicated to so shallow a story. This movie, which cost $\$ 60$ million to make, but earned roughly $\$ 13$ million on its first weekend and made a total lump of $\$ 58$ million domestically. In addition, it also solidly fared abroad, with $\$ 79$ million and\$137million worldwide. In total, this movie made $\$ 166,694,840$ from worldwide and home video rentals. It also received a Brigadoon Award for Historical Accuracy. (2)Even writer Tony Parsons later on called it "a stinker of a picture called Far And Away", which was far and away the worst film I have ever seen." (Far and Away. From Wikipedia.). However, the writer of this paper deems that this movie is an overall culmination of art, history and culture of America; a brand-new attempt to read the American dream in this 21century; and therefore of great historic and realistic significance.

\section{JOSEPH:A HUMBLE BUT YOUNG BIG -}

\section{DREAMER,WHO STUMBLES AND FALLS AND RISES AGAIN TO} ACCOMPLISH HIS LAND DREAM STEADFASTLY AND

\section{RESOLUTELY}

This movie starts in an aura of subtle and restrained mellifluous tone color of Scottish bagpipe, so its score is a mixture of traditional Irish instrumentation and conventional orchestra, which signify an epic upbeat breath of fresh air, symbolize the upcoming of a new era, and indicate the impending radical transformation. In 1893Ireland, Joseph's family home is burned down by Stephen, her father's arrogant manager because of unpaid rent. Joseph is hardworking, pure and clean, honest and down to earth which is in sharp contrast to his two idle brothers. Upon 
learning his father is fatally wounded in a fight with landlord's gang, he goes to great length to nurse him tenderly. As he lie dying, he said to Joseph:"You've got all kinds of oddities clattering about in your brain. So did I when I was young as you. But dreams, my boy, in this poor corner of the world, end up in a glass of gale." "Without land a man is nothing, they say. Land is a man's very own soul. You are hoping for a miracle, Joseph. But if you manage it, by God, your old Da will be smiling down on you from heaven above." (Bob Dolman \&Ron Howard.1992. p11-12) with that promise, that will, his father firmly plants the landdream in his mind. Vowing to revenge, Joseph starts his journey of life on a little donkey with the blessing of the alleged "Moonlight Knight", plus an old gun. Along the way, how cute! He loses his donkey and the trail of the landlord, and settles faintly in the lord's stable. By chance, while peeping Shannon's undressing herself, he is stabbed by her. For the very first time, he witnesses the grandeur, splendor and beauty of lord's manor, and his foe is right there. What a simple, brusque and rash guy! Subsequently, in the course of healing in the house, he develops a feeling for Shannon and acts as a "servant" for her to avoid scandal, convinced that he can also stake a land claim in Texas Territory.

In Boston, they confront an entirely new world and experience. Joseph enjoy life here of freedom and equality very much. Just as he says to Shannon:'We've been here a day and look at the welcome we've got. Would you like a job? Here you go. Would you like a room? Here you go. How about some land? Get a horse and help yourself!" (Bob Dolman \&Ron Howard.1992.p50) They managed to lodge together and get a job of plucking chickens in a processing plant . They cherished their hard-earned coins. Joseph get some more money by boxing. At this time, they bickers about how to spend the money. With more money, Joseph worked his way up as a successful boxer. He purchases some suits and a host of hats, behaving like a true gentleman, incurring not a bit attention from his "sister", only to be blamed for squandering money. On one occasion, when losing the competition, they were robbed of the money saved and driven out of their asylum to the frozen streets both penniless and homeless.

On a snowy evening, they transpass into a big house, pretend to be a couple and display some tender moments and soft intimate feelings, yet the owner find and shot Shannon on her back, severely wounded. Exhausted and out of resources, Joseph send Shannon to her new home in Boston to be tended after. They departed after that incident. Joseph worked on the railway blast some tunnels, dig some coals etc. Yet they could not let go of their dear dream. So, fate arranged their reunion in Oklahoma. They took part in the race to get their land. They grabbed the bridle tightly and penetrated the banner which symbolized the accomplishment of their dream. They become heroes at the end and settle there for ever. I dream, I strive, I get it, therefore, I am! He keeps his promise to his father:"Not my dreams, Da. I will own my own land someday. " (Bob Dolman \&Ron Howard.1992.p11). Despite some setbacks and sufferings, he finally made it, not only his dream of land but also that of beauty.

\section{SHANNON: AN OBSTINATE, HEADSTRONG BUT Modern LADY Who Downgrades Herself to MAKE HeR DREAM COME TRUE BY HOOK OR BY CROOK}

Born with a silver spoon in her mouth, Shannon doesn't rest content with her noble position and comfort. She is modern and crave for the adventurous life envisioned by a note paper promising free land in America. Once in her house, instead of delighting the guests and her suitor--Stephen by playing wonderful music, she wantonly plays band music from America, which greatly astonish them all. As with what she disclose herself to Joseph meaningfully:'I'm modern and I'm going to a modern place. You're not the only one who's trapped. If I stay here my mother will turn me into one of her stuffy friends. No thank you! I'm a little more interesting than that. I'm very smart and I'm very modern, and that's all you need to know about me." (Bob Dolman \&Ron Howard. 1992. p28-29). From this point, she is just like a piece from the old block of her father--Christie who once blurt out:"-.I crave adventure, boys If I had wings I'd fly to the stars." (Bob Dolman \&Ron Howard. 1992. p17). "But Shannon is rebellious, and like her father she yearns for freedom." (Bob Dolman \&Ron Howard. 1992. p21). So she elope with Joseph and bound for Boston with some asset of ancient silver spoon from her home. All the way, she acts as a master and served by her follower Joseph with tea, polishing shoes and guard for her security. She encounters Mr. McGuire who promises to help her to exchange her spoons for dollars. But in Boston, she is robbed of all her wealth. Starting from scratch. They are brought to Irish immigrant community to see the biggest man named Kelly, who finds them lodging and jobs, but only one room. They pretend to be brother and sister: becoming attracted to each other but keeping up a front of indifference. Shannon is not used to the life of a chicken-plucker, dirty and exhausting, being supervised and enslaved by an ugly man and earned little cents. She saves her hard-earned money and even ventures to go on stage as a burlesque dancer. This is real life, harsh and ruthless. Later on, losing in the boxing, they become bankrupt and wander on the cold streets starving. After their transpassing incident, she is taken good care of by her parents and Stephen.

After sometime, she manages to arrive in Texas and happens to see Joseph. There, she still display s obvious feelings for Joseph, who is sort of tender-loving-care for her, whereas Stephen only blames and scolds her. She made the critical decision of choosing Joseph over Stephen towards the end of the movie. They get reunited and settle therefor keeps. Wonderful, Isn't it? She realizes her will of claiming her land:"-I'm going to have some. And I'll raise horses on it and I will ride them any way I please!" (Bob Dolman \&Ron Howard.1992.p29.)

\section{THEIR LAND-CLAIMING DREAM LINKS THEIR FATE TOGETHER, AND THROUGH THICK AND THIN, THEY WiTNESS ITS COMING INTO BEING}

Towards the end of this movie when Joseph is crushed under the weight of Stephen's horse and hid head smashes against a rock, Shannon makes her choice and blurts out her 
long-cherished words of her heart:'I love you! I loved you from the first time I saw you-!" (Bob Dolman \&Ron Howard.1992.p140). The writer would like to elaborate a bit. Their first encounter occurs in the stable! She hurts him very badly. While Joseph is healing his wound, out of her strong curiosity for the male sex organ, she uncovers the pot that covers his private parts for two times, so much so that her maid asks to protect the innocence of her eyes. Soon, in the glaring eye of her guests, she leaves a deep impression of Joseph's striking down of Stephen and stepping over his neck. In other words, he can protect her! So she comes up with the idea of eloping with her, revealing him their dream:'Land! They give it away for free. Come with me. You can be my serving boy." (Bob Dolman \& Ron Howard.1992. p97). AS the saying goes, it's easy to fall in love but difficult to live with each other. Yet generally, they learn to adapt, accept and tolerate each other, though sometimes not so easily and smoothly due to their status and position consciousness. Like one dialogue between them:'But it's so much money. You'll have Oklahomahorses, wagons, everything. You'll never have to box, ever again. This will get us out of here."Joseph looks at Shannon. Joseph: "Us?" (Bob Dolman \&Ron Howard.1992.pp.7576). Too sensitive too practical an issue is social status entailing too much! They gradually become interdependent and cannot do without the other particularly in a bizarre new world. Despite Stephen's intensive and TLC (tender loving care) in Boston, Shannon's beautiful eyes encourage Joseph to take the land he has won in Texas-their destiny. Thus, Stephen has to get out of the picture at the destination. They play a beautiful and wonderful drama of one's destiny lying in one's own hands, not in their parent's. The once rash young fellow of Joseph rises from rags to riches through his own ceaseless efforts and also marries a wealthy woman of his own liking. As a Chinese two-part allegorical saying goes: "A toad lusting after a swan's flesh-aspiring after something one is not worthy of." In the context of this movie, the toad not only tastes swan's flesh, but also finds it delicate and delicious! In a word, Joseph reaps all the royal rewards of his risk-taking and laughs all the way to the bank with his loving Shannon.

\section{CONCLUSION}

From above analysis, this movie, in the writer's eyes, can not only help the native speakers to review the encirclement of their ancestors in a vivid and visual manner, but also teaches them very clearly that as long as they have personal dreams, they would strive for it, manage it, and make it so long as they remain alive. "Simply go and get it, Period!" for dreams and hopes can make this life colorful and full, and not in vain. For non-natives, this movie broadens their horizons and brings them a realistic version of American Dream. For the writer of this paper, this movie plugs the gap of his mental map towards Ireland in movie medium, and gained a detailed and deeper perspective of it.

\section{REFERENCE}

[1] Amy Jentoft. <ajentoft@alpha.albion.edu> http://www.imdb.com/title/tt0104231plotsummary?ref_+=tt_ov_pl.

[2] Bob Dolman, Ron Howard. "Far and Away". New York: New market Press 1992.

[3] "Far and Away" from Wikipedia. The free Encyclopedia. http://en.wikipedia.org/wiki/Far_and_Away.

[4] Jian "Far ang. Away". http://movie.douban.com/review/6130581.2013-06-22 22:57:41.

[5] Nikejidemanba. The Price of Land Derives from its Freedom-Movie Review of "Far and Away". http://tieba.baidu.com/p/945834690.

[6] Synopsis for "Far and Away" (1992) More at IMDbPro. http://www.imdb.com/title/tto1o4231/synopsis?ref_=ttpl_pl_syn.

[7] Weifeng Geng. Joseph's Aspiring for Dreams in "Far and Away". Movie Literature. 2014. No.20. pp74-75.

[8] Wu Jian . Dreams are not "Far and Away". http://movie.douban.com/review/4588336/

[9] Wei Wei. A Glimpse of American History and Culture from "Far and Away". Movie Literature. 2012. No.19. pp99-100,

[10] Xiongxin Jiao. "Far and Away". DoubanMovie. http://movie.douban.com/review/1334682.2008-03-24 20:23:45.

[11] Yang Miao. The Similarities and Contrasts Concerning Sino-US Western Development Strategy from the Perspective of "Far and Away". Social Science.p550. 